\title{
WYBRANE ZAGADNIENIA PRAWNE DOTYCZĄCE UDZIAEU SEJMU W STANOWIENIU PRAWA UNII EUROPEJSKIEJ
}

\section{UWAGI WSTĘPNE}

Udział Polski w integracji europejskiej doprowadził do znaczącego przekształcenia zadań prawodawcy krajowego, w tym Sejmu, a więc organu, który odgrywa główną rolę w procedurze ustawodawczej. Z jednej strony Sejm utracił wiele tradycyjnych uprawnień, ponieważ liczne sprawy, które należały wcześniej do jego kompetencji, zostały powierzone organom prawotwórczym Unii Europejskiej, z drugiej - parlamenty narodowe państw członkowskich uzyskały nowe możliwości działania, również w zakresie wykraczającym poza granice państwowe. Integracja unijna znajduje wyraz także w zacieśnianiu związków między prawodawcą krajowym a organami UE oraz między poszczególnymi parlamentami narodowymi w UE. Ten wciąż nowy, europejski wymiar działalności parlamentarnej podlega złożonej, wielowątkowej regulacji, która obejmie w szczególności zasady oddziaływania Sejmu na kształt prawa UE. W artykule podjęto niektóre zagadnienia prawne dotyczące tej sfery funkcjonowania Sejmu. Ich wybór podyktowany został znaczeniem w praktyce parlamentarnej - rozważane kwestie mają charakter problemowy, a ich uporządkowanie przyczyniłoby się do wzmocnienia roli Sejmu w Unii Europejskiej.

\section{CHARAKTER KRAJOWEJ REGULACJI DOTYCZĄCEJ UDZIAŁU SEJMU W STANOWIENIU PRAWA UE}

Zaangażowanie Sejmu w unijny proces integracyjny wyraża się nie tylko w wykonywaniu prawa Unii Europejskiej, lecz także we wpływie na proces jego stanowienia. Podobnie do działań implementacyjnych, rola Sejmu w tworzeniu prawa UE opiera się zarówno na podstawach unijnych, jak i krajowych ${ }^{1}$. W warstwie unijnej podstawy te określaja art. 12 Traktatu o Unii Europejskiej, dotyczący zasad demokratycznych i uprawnień parlamentów narodowych w UE, oraz dołączone do traktatów protokoły w sprawie roli par-

${ }^{1}$ Podstawę obowiązku implementacyjnego stanowi art. 4 ust. 3 Traktatu o Unii Europejskiej, Dz. Urz. UE C 202 z 7 czerwca 2016, s. 13 (dalej jako: TUE). 
lamentów narodowych w UE (Protokół nr 1) i w sprawie stosowania zasad pomocniczości i proporcjonalności (Protokół nr 2). Warstwę krajową tworzy ustawa o współpracy Rady Ministrów z Sejmem i Senatem w sprawach związanych z członkostwem Rzeczypospolitej Polskiej w Unii Europejskiej (tradycyjnie określana mianem ustawy kooperacyjnej) ${ }^{2}$ i niektóre postanowienia regulaminu Sejmu ${ }^{3}$. Oba poziomy regulacji dotyczącej roli Sejmu w tworzeniu prawa UE - unijny i krajowy - są względem siebie zasadniczo samoistne i komplementarne. Oznacza to w szczególności, że ustawa kooperacyjna nie tyle wykonuje prawo UE, ile zajmuje przestrzeń regulacyjna, która pojawiła się w wyniku przystapienia Polski do UE, krajowe rozwiązania ustawowe zaś uwzględniają rozwiązania unijne, lecz, w sensie normatywnym, nie są przez nie zdeterminowane. Stricte implementacyjny charakter mają wyłącznie niektóre postanowienia regulaminu Sejmu ${ }^{4}$.

Z punktu widzenia regulacji krajowej, w tym wewnętrznej systematyki szczegółowych postanowień ustawy kooperacyjnej i regulaminu Sejmu, zaangażowanie Sejmu i jego organów w sprawy unijne dzieli się na dwa ściśle wyodrębnione obszary: stanowienie i wykonywanie prawa $\mathrm{UE}^{5}$. Podział ten ujawnia się w wymiarze instytucjonalnym i proceduralnym.

Udział Sejmu w procesie stanowienia prawa UE, wyrażajacy się przede wszystkim w pośrednim wpływie krajowego prawodawcy na proces tworzenia aktów prawa wtórnego przez instytucje unijne, to wyłączna domena wyspecjalizowanego organu parlamentarnego, tj. sejmowej Komisji ds. UE ${ }^{6}$. Komisja ta działa na podstawie szczególnych, stosowanych tylko przez nią reguł proceduralnych, które są ustanowione głównie w rozbudowanej regulacji ustawy kooperacyjnej i sprowadzają się przede wszystkim do uprawnień tej komisji do wydawania opinii o określonych dokumentach unijnych oraz powiąanych z tymi dokumentami stanowiskach (informacjach) RM. Ustawa kooperacyjna określa szczególne typy takich opinii - wedle ich różnego przedmiotu ${ }^{7}$. Komisyjne prace opiniodawcze dotyczą zatem dokumentów instytucji UE, które przekazywane są do Sejmu w wykonaniu obowiązów traktatowych ${ }^{8}$, oraz rządowego komentarza do tych dokumentów, prezentującego linię polityki państwa, która została przyjęta w danej sprawie przez RM.

\footnotetext{
${ }^{2}$ Ustawa z 8 października 2010 r. o współpracy Rady Ministrów z Sejmem i Senatem w sprawach związanych z członkostwem Rzeczypospolitej Polskiej w Unii Europejskiej, Dz. U. Nr 213, poz. 1395.

${ }^{3}$ Uchwała Sejmu Rzeczypospolitej Polskiej z 30 lipca 1992 r. - Regulamin Sejmu Rzeczypospolitej Polskiej, M. P. 2012, poz. 32 ze zm. Por. rozdz. 13a Regulaminu Sejmu (Komisja do Spraw Unii Europejskiej).

${ }^{4}$ Por. art. 148ca-148cf Regulaminu Sejmu.

${ }^{5}$ Podział ten określa także wewnętrzną systematykę wcześniejszej wersji ustawy kooperacyjnej - ustawy 11 marca 2004 r. o współpracy Rady Ministrów z Sejmem i Senatem w sprawach związanych z członkostwem Rzeczypospolitej Polskiej w Unii Europejskiej (Dz. U. Nr 52, poz. 515, oraz 2005, Nr 11, poz. 89 i Nr 160, poz. 1342); por. Mik, Pawłowski (2004): 258-273; (2009): 46-104.

${ }^{6}$ Por. Cieślik (2015a): 21-22; (2015b): 176-180.

7 Art. 7, 8, 10 i 11 ustawy kooperacyjnej. Por. Pudło (2014): 54.

${ }^{8}$ Art. 1 i art. 2 Protokołu nr 1, Dz. Urz. UE C 202 z 7 czerwca 2016, s. 203.
} 
Do pierwszej kategorii dokumentów należą najważniejsze projekty aktów prawnych UE - projekty aktów ustawodawczych UE - oraz dokumenty konsultacyjne (zielone księgi, białe księgi, komunikaty i sprawozdania Komisji Europejskiej), a zatem zarówno projekty wiążącego prawa UE (hard law), jak i akty niewiążące (soft law). W praktyce komisji ds. UE wszystkie dokumenty, które Sejm otrzymuje od instytucji unijnych, określane są mianem dokumentów UE. Drugą kategorię dokumentów stanowią opracowywane projekty stanowisk RP o projektach aktów prawnych UE, stanowiska RP, jakie RM ma zamiar zajać podczas rozpatrywania projektu aktu prawnego UE w Radzie, oraz informacje o sprawach związanych z członkostwem RP w UE, o przebiegu procedur stanowienia prawa UE i o stanowiskach RP zajmowanych w trakcie tych procedur 9 . Te dokumenty opracowywane sa przez rządowy Komitet ds. Europejskich, który działa w tym zakresie w imieniu RM ${ }^{10}$.

Upraszczajac, dyspozycje i uwagi zawarte w opiniach komisji ds. UE maja za przedmiot różne dokumenty UE i towarzyszące im dokumenty RM. Takie opinie nie są formalnie wiążące dla RM, lecz - zgodnie z ustawą kooperacyjna - „powinny stanowić podstawę stanowiska Rzeczypospolitej Polskiej”11, co oznacza, że nie moga być one (bez sankcji) przez RM ignorowane ${ }^{12}$.

Wykonywanie prawa UE, które w Sejmie polega głównie na stanowieniu ustaw wykonujacych prawo UE i nieuchwalaniu ustaw sprzecznych z tym prawem $^{13}$, nie podlega szczególnej regulacji prawnej i realizuje się zasadniczo $\mathrm{w}$ ramach standardowej procedury ustawodawczej. Wyjątek w tej mierze stanowią nieliczne przepisy proceduralne, dyscyplinujace porządek postępowania ustawodawczego z uwagi na cel implementacyjny, które zawiera regulamin Sejmu i ustawa kooperacyjna ${ }^{14}$. W przeciwieństwie do stanowienia prawa UE, sejmowa działalność implementacyjna jest domeną różnych sejmowych komisji branżowych, które podejmują - w ramach ich różnej właściwości rzeczowej - zwykłe działania legislacyjne w toku sejmowej procedury tworzenia prawa. Teoretycznie, biorac pod uwage zakres jej kompetencji, sejmowa Komisja ds. UE mogłaby, na równych zasadach z komisjami branżowymi, angażować się także w implementację, w praktyce jednak niemal w ogóle tego nie czyni ${ }^{15}$.

Na tle tych ustaleń, dotyczących podstaw prawnych zaangażowania Sejmu w sprawy unijne, warto sformułować kilka ogólniejszych uwag. Po pierwsze, ścisły podział ról na gruncie regulacji krajowej, wyrażający się w koncentra-

${ }^{9}$ Art. 7 ust. 1 i ust. 2 , art. 8 ust. 1 , art. 10 ust. 1 , art. 11 ust. 1 i art. 3 ust. 2 ustawy kooperacyjnej.

${ }_{10}$ Art. 3 ustawy z 27 sierpnia 2009 r. o Komitecie do Spraw Europejskich (Dz. U. 2017, poz. 2078).

11 Art. 13 ust. 1 ustawy kooperacyjnej.

12 Aktualność zachowują w tym względzie uwagi zawarte w komentarzu do poprzedniej ustawy kooperacyjnej: Mik, Pawłowski (2004): 250 i 270; (2009): 85-86.

13 Barcz (2009): 34.

14 Rozdz. 5a Regulaminu Sejmu i rozdz. 4, art. 18 ustawy kooperacyjnej.

${ }^{15}$ W VIII kadencji Sejmu do komisji ds. UE skierowanych zostało tylko siedem projektów ustaw, z czego cztery dotyczyły zgody na ratyfikację umowy międzynarodowej. Podobną prawidłowość można odnotować we wcześniejszych kadencjach (kadencja VII - 12 projektów ustaw, kadencja VI - 10 projektów ustaw). 
cji uprawnień dotyczacych stanowienia prawa UE w jednym organie i jednoczesnym rozproszeniu zadań dotyczacych jego wykonywania między wieloma organami, jest zupełny (stanowienie i wykonywanie aktu prawa UE w Sejmie to dwa odrębne, niepowiązane procesy) i typowy (rozwiązanie to występuje $\mathrm{w}$ wielu zagranicznych porządkach parlamentarnych: np. Niemcy, Wielka Brytania, Hiszpania, Dania) ${ }^{16}$. Podział ten umacnia brak podstaw regulaminowych prowadzenia współpracy między komisją ds. UE, rozpatrująca projekt aktu prawnego UE, z komisjami branżowymi, które - na późniejszym etapie, już po zakończeniu unijnej procedury prawodawczej - angażują się w procedurę jego wykonania (implementacji). Komisja ds. UE nie może, w szczególności, zasięgnąć opinii innej komisji sejmowej (komisji branżowej) na temat rozpatrywanego przez siebie projektu aktu prawnego UE. Biorąc pod uwagę historię tworzenia prawa - i prezentowane przez prawodawcę uzasadnienie wprowadzanych zmian ${ }^{17}$ - powód wprowadzenia tego podziału nie był przy tym systemowy, lecz wyłącznie pragmatyczny: specjalne zadania krajowego prawotwórcy wymagały ustanowienia ich wyspecjalizowanego wykonawcy.

Po drugie, niezależnie od intencji, które deklarował pierwotnie prawodawca, regulacyjne wyodrębnienie roli Sejmu jako, z jednej strony, organu uczestniczącego w stanowieniu prawa UE, oraz z drugiej - organu, który to prawo wykonuje, wspiera się również na ważnej racji ustrojowej. O ile bowiem wykonywanie prawa UE mieści się w ramach tradycyjnej funkcji ustawodawczej parlamentów narodowych, a zatem dokonuje się na gruncie reguł stanowienia prawa krajowego (niekiedy w pewnym stopniu zmodyfikowanych), o tyle udział w stanowieniu prawa UE jest zadaniem nowym, zasadniczo wykraczającym poza tradycyjne funkcje parlamentarne i wymaga dopiero ustrojowego przyporządkowania.

Warto odnotować, że ten ważny problem kwalifikacyjny został podjęty przez Trybunał Konstytucyjny już w pierwszych miesiącach polskiej obecności w UE. W styczniu 2005 r. Trybunał wydał wyrok, w którym przypisał parlamentarne kompetencje w sferze tworzenia prawa UE do funkcji ustawodawczej - a nie kontrolnej. Zdaniem Trybunału w przypadku opinii wydawanych przez sejmową komisję ds. UE w grę wchodzi „nowa szczególna postać realizacji kompetencji mieszczących się w prerogatywach władzy ustawodawczej”. Jak wskazywał Trybunał: „W powszechnie przyjętym i utartym rozumieniu wykonywanie funkcji ustawodawczej ogranicza się wyłącznie do stanowienia prawa wewnętrznego - wydawania aktów normatywnych rangi ustawowej. Sytuacja diametralnie zmieniła się po 1 maja 2004 r., z tym bowiem dniem polski parlament utracił w znaczącym stopniu wpływ na kształt prawa powszechnie obowiązującego w Polsce. Należy przyjąć, że skoro istotą wykonywania przez parlament funkcji ustawodawczej jest możliwość oddziaływania w możliwie najszerszym zakresie na obowiązujące w kraju prawo, to do tej właśnie funkcji zaliczyć trzeba uprawnienia parlamentu związane z wpływaniem - choćby

16 Serowaniec (2016):14-76; Adamiak (2018): 32-34.

17 Uzasadnienie poselskiego projektu uchwały w sprawie zmiany Regulaminu Sejmu Rzeczypospolitej Polskiej, Druk sejmowy IV kadencji nr 2160. Por. Wojtyczek (2018): 709. 
w ograniczonym stopniu - na treść zajmowanego na forum Rady Unii Europejskiej stanowiska Polski w kwestiach unijnych aktów prawnych"18.

W ocenie Trybunału właściwym punktem odniesienia oceny ustrojowego znaczenia kompetencji komisji ds. UE do wydawania opinii na podstawie ustawy kooperacyjnej jest art. 95 ust. 1 (funkcja ustawodawcza), a nie ust. 2 (funkcja kontrolna) Konstytucji RP. Istnieć ma zatem „wspólny mianownik”, nakazujacy ocenianie z tej samej perspektywy typowych efektów legislacji: (1) źródeł prawa: ustaw i (2) quasi-wiążących opinii Komisji ds. UE (opinia powinna stanowić podstawę - prezentowanego przez RM - stanowiska RP, art. 13 ust. 1 ustawy kooperacyjnej).

Rozstrzygnięcie Trybunału miało ogromne znaczenie w kontekście rozważań o problematyce prawnej udziału Sejmu w stanowieniu prawa UE ${ }^{19}$. Rzecz jednak w tym, że przyjęte wówczas przez Trybunał - i od początku kontestowane przez wielu ${ }^{20}$ - przyporządkowanie całkowicie zawodzi jako podstawa wykładni systemowej, która polegałaby na powiązaniu reguł udziału Sejmu w stanowieniu prawa UE z szerszym kontekstem regulacyjnym, dotyczacym stanowienia prawa w Polsce, pozwalając choćby wyjaśnić w ten sposób liczne - i ważne w praktyce stosowania prawa - wątpliwości interpretacyjne. Wbrew konsekwencjom takiej kwalifikacji, reguły tworzenia prawa w Sejmie nie sa - i chyba nie moga być - żadnym punktem odniesienia w trakcie sejmowych działań dotyczących stanowienia prawa UE. „W efekcie” rozstrzygnięcia Trybunału krajowe reguły udziału Sejmu w tworzeniu prawa UE „pozostaja” więc (stosunkowo) wyizolowanym komponentem w systemie krajowego prawa parlamentarnego.

Po trzecie, w kontekście uwag o krajowej regulacji, która dotyczy zaangażowania Sejmu w tworzenie prawa UE, warto wspomnieć o roli służb parlamentarnych. Służby te uczestnicza - na zasadach określonych na podstawie regulaminu Sejmu - w postępowaniach sejmowych i mają duży wpływ na kształt parlamentarnej praktyki, także w sprawach związanych z członkostwem Polski w UE. W Sejmie za eksperckie wsparcie realizacji zadań unijnych odpowiadaja - poza sekretariatami komisji - Biuro Legislacyjne i Biuro Analiz Sejmowych. Służby te bezpośrednio wspierają posłów w postępowaniu ustawodawczym (BL) i prowadzą obsługę prawną komisji ds. UE, oceniając projekty aktów prawnych UE i związane z nimi stanowiska RM oraz - dzieląc się tą rolą z Ministerstwem Spraw Zagranicznych - opiniując zgodność projektów ustaw z prawem UE (BAS) ${ }^{21}$.

Analiza działań tych służb, podejmowanych w toku procedur parlamentarnych, pozwala dostrzec wiele interesujących zagadnień, które wiążą się z „europejskim” obszarem oddziaływania Sejmu ${ }^{22}$. Zagadnienia te maja nie-

18 Wyrok TK z 12 stycznia 2005 r., K 24/04.

19 Balicki (2019): 37-40 i cytowana tam literatura.

20 Por. zdania odrębne do wyroku K 24/04 sędziów Jerzego Ciemniewskiego, Ewy Łętowskiej i Janusza Niemcewicza oraz głosy doktrynalne Mik, Pawłowski (2005): 134-142, łagodniej - Wójtowicz (2008): 81.

21 Art. 34 ust. 8, art. 42 ust. 4, art. 70 Regulaminu Sejmu.

22 Por. Pawłowski (2006): 173-190; Cieślik (2016): 103-116. 
kiedy wręcz systemowy charakter. Warto wskazać i szerzej rozważyć trzy najważniejsze spośród nich: (1) brak reguł - typowo związanych z wykonywaniem funkcji ustawodawczej - stanowiących podstawę oceny „prawotwórczej” praktyki sejmowej Komisji ds. UE; (2) brak reguł zapewniających skuteczność działań podejmowanych przez Komisję ds. UE oraz (3) brak reguł dotyczących reprezentacji komisji (członków komisji) na forum międzynarodowym.

\section{KONTROLA DZIAŁAŃ SEJMOWEJ KOMISJI DO SPRAW UNII EUROPEJSKIEJ}

Pierwsza trudność wiąże się z tym, że procedura wydawania opinii przez komisję ds. UE nie podlega w zasadzie żadnej kontroli, ani wewnętrznej, ani zewnętrznej. Wydawanie opinii nie stanowi, w szczególności, elementu szerszego, podlegającego sformalizowanej ocenie postępowania parlamentarnego. Inaczej niż w przypadku tradycyjnych postępowań ustawodawczych, które podlegaja kompleksowej ocenie Trybunału Konstytucyjnego, efekty postępowania komisji ds. UE - czyli, według kwalifikacji Trybunału, efekty wykonywania przez Sejm funkcji ustawodawczej - nie podlegają ocenie żadnego organu. Nie istnieje więc procedura umożliwiająca podważenie ważności (legalności) aktów tej komisji ze względu na naruszenia prawa popełnione $\mathrm{w}$ trakcie ich wydawania. Jedyną dostępną w tej mierze - i niewykorzystana dotychczas w praktyce - opcję dyscyplinujacca stanowią uchwały interpretacyjne Prezydium Sejmu, na podstawie których komisja może zostać zobowiązana do wyeliminowania wadliwej praktyki ${ }^{23}$.

Należy podkreślić, że brak instancji, która obiektywnie oceniałaby efekty i procedurę pracy Komisji ds. UE, jest bardzo dotkliwy - choćby ze względu na tworzone w ten sposób ryzyko upolitycznienia (z natury dość neutralnych politycznie) kwestii regulaminowych. W związku z tym brakiem w toku w stosowania ustawy kooperacyjnej pojawiają się istotne - i proceduralnie nierozstrzygalne - wątpliwości interpretacyjne. Dotyczą one między innymi zagadnień tak podstawowych, jak przedmiot i zakres opinii Komisji ds. UE oraz ich adresat. Warto poświęcić więcej uwagi obu tym wątpliwościom.

Posługując się sformułowaniem Trybunału Konstytucyjnego z przywołanego wyroku, można powiedzieć, że ustawa kooperacyjna „nie jest w pełni klarowna”, między innymi w odniesieniu do przedmiotu opinii Komisji ds. UE. Na pierwszy rzut oka sprawa wydaje się przedstawiać jasno. Ustawa wskazuje, że przedmiotem opinii o projektach aktów ustawodawczych UE (art. 7 ustawy kooperacyjnej) sa projekty aktów ustawodawczych UE, a przedmiotem opinii wydawanych na podstawie art. 10 i 11 ustawy kooperacyjnej - odpowiednio: stanowiska RP zajmowane w trakcie procedur stanowienia prawa UE i stanowiska RP, jakie RM ma zamiar zajać podczas rozpatrywania projektu aktu

${ }^{23}$ Art. 12 pkt 3 Regulaminu Sejmu: Prezydium Sejmu dokonuje wykładni regulaminu Sejmu, po zasięgnięciu opinii Komisji Regulaminowej i Spraw Poselskich. 
ustawodawczego UE w Radzie. Na tle prostego odczytania przepisów ustawy powstają jednak liczne pytania. Nie jest w szczególności pewne, czy systemowo uzasadnione jest wydawanie w trybie art. 7 ustawy kooperacyjnej opinii o projekcie aktu prawnego UE w sytuacji, gdy komisja nie zna projektu stanowiska RP dotyczącego tego projektu, w tym stanowiska dotyczącego zgodności tego projektu z zasadą pomocniczości. Dodatkowo wątpliwość budzi, czy dopuszczalne jest wydawanie opinii w trybie art. 10 i art. 11 ustawy kooperacyjnej (a więc opinii o stanowiskach RP) w sytuacji, gdy komisja nie dysponuje informacją o projekcie aktu prawnego UE, którego stanowiska te bezpośrednio dotycza. Wreszcie, nie ma jasności, czego mają dotyczyć wypowiedzi komisji zawarte w jej opiniach: tekstu projektu aktu prawnego UE (a więc propozycji poprawek - funkcja ustawodawcza), czy też prezentowanego przez RM stanowiska na temat projektu aktu prawnego UE (postulaty komisji kierowane do RM, stanowisko komisji kierowane do RM - funkcja kontrolna).

Ustawa kooperacyjna nie wskazuje wprost, kto jest adresatem opinii wydawanych przez Komisję ds. UE. W jej postanowieniach brak jest w szczególności sformułowania takiego jak w art. 159 i art. 160 Regulaminu Sejmu (dezyderat może być skierowany do, komisja może przedstawić opinię organom...). W tym stanie rzeczy pojawiły się w praktyce sejmowej propozycje wydawania przez Komisję opinii na temat projektów aktów prawnych UE, które to opinie nie miałyby żadnego adresata i byłyby uchwałami (oświadczeniami) Komisji zawierającymi jej stanowisko w określonej sprawie ${ }^{24}$.

Wobec zarysowanych watpliwości w praktyce komisji przyjmowana jest najczęściej wykładnia proponowana przez służby sejmowe, odczytująca instytucje ustawy kooperacyjnej przede wszystkim w świetle funkcji kontrolnej, nie ustawodawczej ${ }^{25}$. Takie -jak się wydaje solidniej ugruntowane systemowo-odczytanie postanowień ustawy umożliwia też skuteczniejszą realizację uprawnień komisji. W konsekwencji tego założenia należy przyjąć, że przedmiotem opiniowania sa - w przypadku każdej z opinii wydawanych przez Komisję ds. UE - stanowiska RP, które dotyczą działań przedstawicieli RM na forum UE. Dzieje się tak nawet wówczas, gdy literalnie opinia dotyczy wyłącznie projektu aktu prawnego UE (art. 7 ustawy kooperacyjnej). Warto przypomnieć, że zgodnie z art. 148c ust. 2 regulaminu Sejmu, opinia Komisji ds. UE zawiera stanowisko w postaci akceptacji lub braku akceptacji stanowiska RM. Komisja może sformułować w opinii również zalecenia dla Rady Ministrów. Należy przyjąć, że przywołany przepis regulaminowy dotyczy także tych opinii Komisji ds. UE, które sa wydawane na podstawie ustawy kooperacyjnej ${ }^{26}$. W konsekwencji przyjętych założeń interpretacyjnych należy uznać, że gwarantowana na gruncie art. 7 tej ustawy możliwość wydania opinii bez zapoznania się z projektem stanowiska RP powinna być traktowana jako wyjątkowa (w sytuacji, gdy RM, naruszając ustawę, nie przedstawi projektu stanowiska RP

${ }^{24}$ Por. art. 69 ust. 2 pkt 2 Regulaminu Sejmu.

${ }_{25}$ Pawłowski (2006): 84. Por. też doktrynalna propozycja szerokiego ujęcia funkcji kontrolnej Sejmu: Wójtowicz (2008): 77-92.

${ }^{26}$ Por. Wojtyczek (2018): 718-719. 
o projekcie aktu prawnego UE). Dodatkowo wydawanie opinii o stanowiskach RM, o których mowa w art. 10 i art. 11 ustawy kooperacyjnej, a zatem opinii dotyczacych bezpośrednio stanowisk prezentowanych przez RM, wobec braku informacji o projekcie aktu prawnego UE należałoby uznać generalnie za niedopuszczalne. Komisja ds. UE nie powinna w żadnym wypadku wydawać opinii na temat stanowiska RP, nie znając jego rzeczywistego przedmiotu.

Przyjęcie wskazanych założeń interpretacyjnych może pomóc rozstrzygnąc także wątpliwości dotyczące adresata opinii Komisji ds. UE. W każdym przypadku adresatem takich opinii powinien być organ władzy państwowej, którego działalność jest przez tę komisję recenzowana (kontrolowana) - Rada Ministrów. Wniosek ten umacnia dodatkowo art. 13 ustawy kooperacyjnej, który określa skutek prawny tych opinii, stanowiąc, że opinia powinna stanowić podstawę - prezentowanego przez RM - stanowiska RP. Oznaczałoby to, że nie ma możliwości wydawania opinii adresowanych do innych organów niż wskazane w ustawie kooperacyjnej i regulaminie Sejmu. Komisja ds. UE nie mogłaby, w szczególności, kontaktować się bezpośrednio z Komisją Europejska, choćby z tego powodu, że - zgodnie z art. 146 Konstytucji - to nie Sejm prowadzi politykę państwa, w tym politykę zagraniczna. Niedopuszczalność wydawania przez Komisję opinii, które nie są adresowane do nikogo, wynika wręcz z istoty opinii jako aktu o charakterze konsultacyjnym.

\section{WSPÓŁPRACA MIĘDZYPARLAMENTARNA I KONTROLA PRZESTRZEGANIA ZASADY POMOCNICZOŚCI}

Drugim ważnym obszarem wyzwań, z którymi mierzy się Sejm w związku w udziałem Polski w integracji europejskiej, jest współpraca międzyparlamentarna. Ma on szczególne znaczenie w związku z nowymi, lizbońskimi uprawnieniami parlamentów narodowych. Z wejściem w życie Traktatu z Lizbony parlamenty narodowe zostały wyposażone na poziomie prawa UE, m.in. w prawo prezentowania na forum UE własnego stanowiska w sprawach zgodności projektów aktów ustawodawczych UE z zasadą pomocniczości. Uprawnienie to realizowane jest w ramach tzw. procedury „żółtej” lub „pomarańczowej” kartki (art. 12 lit. b TUE, art. 6 Protokołu nr 2). Zgodnie z założeniami procedury traktatowej, zastrzeżenia parlamentów narodowych uzyskują na gruncie prawa UE skutek prawny w momencie, gdy zgłosi je ich odpowiednia liczba zasadniczo konieczne jest zebranie $1 / 3$ głosów parlamentów narodowych lub ich izb. Oznacza to, że dopiero zebranie uzasadnionych opinii w liczbie odpowiadającej 18 głosom parlamentów narodowych (izb tych parlamentów) o niezgodności projektu aktu ustawodawczego z zasadą pomocniczości powoduje, że projektowany akt poddawany jest ponownej analizie przez wnioskodawcę (zwykle Komisję Europejska).

Warto podkreślić, że uprawnienie parlamentu narodowego do zgłoszenia uzasadnionej opinii o zgodności projektowanego prawa UE z zasada pomocniczości stanowi jedną $\mathrm{z}$ bardzo nielicznych kompetencji traktatowych, 
które umożliwiają Sejmowi nawiązanie bezpośrednich relacji prawnych z instytucjami UE - a więc bezpośrednie, a nie zapośredniczone przez RM, oddziaływanie na proces tworzenia prawa $\mathrm{UE}^{27}$. Kompetencja ta ujęta jest jednak w prawie pierwotnym bardzo wasko - i to w wielu wymiarach. Parlamentarne zastrzeżenia dotyczące zgodności z zasadą pomocniczości moga dotyczyć - spośród wszystkich dokumentów UE - wyłącznie projektów aktów ustawodawczych, i to tych tylko, które stanowione są w dziedzinie kompetencji niewyłącznych UE. Zakres bezpośredniej kontroli parlamentarnej prawotwórstwa unijnego ogranicza dodatkowo samo kryterium badania - z racji samej swej natury. Zasada pomocniczości stanowi, z jednej strony, pojęcie niedookreślone, niełatwe do prawniczego zastosowania (wedle niektórych: kryterium polityczne) $)^{28}$. Z drugiej strony zasada ta jest na gruncie traktatowym wyraźnie odróżniana od innych, bliskich jej treściowo zasad prawnych: przyznania i proporcjonalności (których parlamentarna kompetencja nie dotyczy) ${ }^{29}$. Kompetencja kontrolna ograniczona jest wreszcie terminem - można ją realizować w ciagu 8 tygodni od przesłania parlamentowi ocenianego projektu aktu ustawodawczego UE.

W efekcie tych ograniczeń, mimo licznych i szumnych deklaracji o znaczeniu lizbońskich kompetencji parlamentów narodowych (zwłaszcza w kontekście zjawiska deficytu demokracji w UE), parlamenty nieczęsto sięgaja do nowego uprawnienia. Sejm zgłosił dotychczas (w ciagu już niemal 10 lat od wejścia w życie Traktatu z Lizbony) 23 uzasadnione opinie, w tym 4 w ostatniej, VIII kadencji ${ }^{30}$, nie odstając tym rezultatem znacznie od ogólnounijnego stan$\operatorname{dardu}^{31}$. Co więcej, w historii integracji europejskiej tylko trzy razy uzasadnione opinie parlamentów narodowych, dotyczące określonego projektu aktu ustawodawczego UE, osiąnęły próg żółtej kartki (1/3 głosów), który wyzwala traktatowe skutki naruszenia zasady pomocniczości w ramach postępowania

${ }_{27}$ Por. także art. 48 ust. 7 TUE, art. 81 ust. 3 Traktatu o funkcjonowaniu Unii Europejskiej, Dz. Urz. UE C 202 z 7 czerwca 2016, s. 47 (dalej jako: TfUE). Por. Lis-Staranowicz, Galster (2010): 36-37; Mik (2010): 59.

${ }_{28}$ Adamiak (2018): 44 i cytowana tam literatura.

${ }^{29}$ Mik (2019): 36-40.

30 Wniosek dotyczący dyrektywy Parlamentu i Rady zmieniający dyrektywę 96/71/WE Parlamentu Europejskiego i Rady z 16 grudnia 1996 r. dotyczącej delegowania pracowników w ramach świadczenia usług, COM(2016)128 final. Wniosek dotyczący rozporządzenia Parlamentu Europejskiego i Rady w sprawie ustanowienia kryteriów i mechanizmów ustalania państwa członkowskiego odpowiedzialnego za rozpatrzenie wniosku o udzielenie ochrony międzynarodowej złożonego w jednym z państw członkowskich przez obywatela państwa trzeciego lub bezpaństwowca (wersja przekształcona), COM(2016)270 final. Wniosek dotyczący rozporządzenia Parlamentu Europejskiego i Rady w sprawie wewnętrznego rynku energii elektrycznej, COM(2016)861 final. Wniosek dotyczący dyrektywy Parlamentu Europejskiego i Rady w sprawie równowagi między życiem zawodowym a prywatnym rodziców i opiekunów oraz uchylającej dyrektywę Rady 2010/18/UE, COM(2017)253 final.

${ }^{31} \mathrm{~Np}$. w roku 2017 r. parlamenty narodowe UE przedstawiły łącznie 52 uzasadnione opinie, które odnosiły się do 23 projektów aktów ustawodawczych UE, w tym w przypadku 12 projektów uzasadnioną opinię zgłosiła tylko jedna izba. Por. Załącznik do sprawozdania Komisji: Sprawozdanie roczne za rok 2017 w sprawie stosowania zasad pomocniczości i proporcjonalności, COM(2018)490 final. 
legislacyjnego $\mathrm{UE}^{32}$. W żadnym z tych przypadków argumenty parlamentów narodowych, dotyczace naruszenia zasady pomocniczości, nie zostały przy tym uznane i podjęte przez Komisję Europejska. Generalnie zatem mechanizmowi temu brak jest obecnie skuteczności.

$\mathrm{Na}$ tle tych ustaleń sformułować można pewne tezy, dotyczące regulacji w dziedzinie parlamentarnej kontroli zasady pomocniczości. Pierwsza teza dotyczy przyczyny braku skuteczności mechanizmu parlamentarnej kontroli przestrzegania zasady pomocniczości. Uznać należy, że brak ten stanowi efekt niedostatecznej współpracy parlamentów narodowych na etapie opiniowania projektów aktów ustawodawczych UE, podczas traktatowych 8 tygodni. Ścisła współpraca tych parlamentów jest zaś koniecznym warunkiem skuteczności traktatowej kompetencji i powinna obejmować w pierwszym rzędzie uzgodnienia dotyczące stanowisk $\mathrm{w}$ sprawie rozpatrywanych projektów - w konsekwencji: skoordynowanie zarzutów (więc względne ujednolicenie „parlamentarnej” koncepcji pomocniczości, naturalnie w oparciu o - wciąż ubogie w tym zakresie - orzecznictwo Trybunału Sprawiedliwości UE). Opinie parlamentów muszą być ponadto przesłane na czas. Należy podkreślić, że zarówno argumenty zawarte w uzasadnionych opiniach, jak i termin ich przesłania moga być przedmiotem kontroli Komisji Europejskiej, która jest traktatowo obowiązana wziąc pod uwagę wyłącznie te opinie, które ściśle spełniają kryteria traktatowe. Teoretycznie Komisja nie musi zatem uwzględniać opinii, które odnoszą się do innych zagadnień (np. wadliwości podstawy prawnej projektowanego aktu lub jego zgodności z zasadą proporcjonalności) lub zostały zgłoszone po terminie ${ }^{33}$.

Druga teza odnosi się do podstaw współpracy międzyparlamentarnej. Brak odpowiedniego współdziałania parlamentów narodowych na etapie formułowania stanowiska w procedurze kartkowej wyraża się m.in. w tym, że przepływ informacji między parlamentami w trakcie tej procedury jest bardzo ograniczony i odbywa się wyłącznie - nieformalnie - za pośrednictwem przedstawicieli parlamentów narodowych przy PE i za pomoca bazy IPEX. Wobec braku rygorów terminowych, informacje docierają do parlamentów ponadto zbyt późno - na takim etapie procedury, który uniemożliwia skuteczne ich wykorzystanie. W związku z tym stanowiska, które one zajmują w procedurze traktatowej, są wzajemnie nieskoordynowane, rozproszone - i w efekcie prawnie nieskuteczne ${ }^{34}$.

${ }^{32}$ Wniosek dotyczący rozporządzenia Rady w sprawie wykonywania prawa do podejmowania działań zbiorowych w kontekście swobody przedsiębiorczości i swobody świadczenia usług, $\operatorname{COM}(2012) 130$ final (niekwestionowany przez Sejm i Senat, wycofany przez KE z innych przyczyn). Wniosek dotyczący rozporządzenia Rady w sprawie ustanowienia Prokuratury Europejskiej, COM(2013)534 final (niekwestionowany przez Sejm i Senat, uchwalony przez Radę i PE). Wniosek dotyczący dyrektywy Parlamentu Europejskiego i Rady zmieniającej dyrektywę 96/71/WE Parlamentu Europejskiego i Rady z 16 grudnia 1996 r. dotyczącą delegowania pracowników w ramach świadczenia usług, $\operatorname{COM}(2016) 128$ final (kwestionowany m.in. przez Sejm i Senat, uchwalony przez Radę i PE).

${ }_{33}$ Mik (2019): 66; Adamiak (2018): 225-226.

${ }^{34} \mathrm{~Np}$. w roku 2017 r. parlamenty narodowe UE przedstawiły łącznie 52 uzasadnione opinie, które odnosiły się do 23 projektów aktów ustawodawczych UE, w tym w przypadku 12 pro- 
Parlamenty w pewnym stopniu zareagowały na wskazane trudności. W praktyce uzasadnione opinie przekształciły się w dodatkowy instrument dialogu politycznego, a więc programu współpracy międzyinstytucjonalnej, który został sformułowany przez Przewodniczącego Komisji Europejskiej we wrześniu 2006 r. Zgodnie z tzw. inicjatywą José Manuela Barroso, parlamenty narodowe państw członkowskich UE są zachęcenie do zajmowania stanowisk w sprawach dotyczaccych działań Unii Europejskiej i przesyłania tych stanowisk bezpośrednio organom UE. W odróżnieniu jednak od procedur określonych w Traktacie z Lizbony, które dotyczą parlamentarnej kontroli poszanowania zasady pomocniczości, problematyka dialogu politycznego nie została wyraźnie uregulowana w prawie UE. Jest to inicjatywa stricte polityczna ${ }^{35}$. W efekcie wskazanych przekształceń, opinie poszczególnych (izb) parlamentów narodowych stanowią głównie medium niesformalizowanego i pozbawionego skutków prawnych oddziaływania krajowego prawodawcy na unijny proces decyzyjny. Taki rezultat nie jest jednak dla parlamentów korzystny i degraduje mechanizm traktatowy. Brak skutku prawnego podejmowanych działań powoduje przecież, że siła głosu danego parlamentu zależy w mniejszym stopniu od siły prezentowanego argumentu (zarzutu naruszenia zasady pomocniczości), a w większym (przynajmniej potencjalnie) od politycznej siły jego państwa w UE.

Wskazane ustalenia prowadzą do sformułowania postulatu dotyczącego umocnienia podstaw prawnych współpracy międzyparlamentarnej. Należy uznać, że wobec braku skuteczności dotychczasowych działań parlamentów w zakresie kontroli przestrzegania zasady pomocniczości przez instytucje UE współpraca międzyparlamentarna powinna zostać zinstytucjonalizowana i oparta na wiążących zasadach. Ścisła i sformalizowana współpraca tych parlamentów umacniałaby ich pozycję w ramach procedury „kartkowej” - i uczyniłaby ją skuteczniejsza. Warto przywołać w tym kontekście regułę kompetencyjna, która umożliwia określenie zasad prowadzenia takiej współpracy w prawie UE. Zgodnie z art. 9 Protokołu nr 1: „Parlament Europejski i parlamenty narodowe wspólnie określają sposób organizacji i wspierania skutecznej i systematycznej współpracy międzyparlamentarnej w ramach Unii”. Regulacyjny potencjał, który drzemie w tym przepisie, nie został dotychczas wykorzystany. Co ważne, proponowana zmiana nie wymagałaby rewizji traktatów.

\section{REPREZENTACJA SEJMU NA FORUM UE}

Trzeci obszar problemowy, który odnosi się do udziału Sejmu w tworzeniu prawa UE, pojawia się w związku z brakiem reguł dotyczących reprezentacji Sejmu i jego organów na forum międzynarodowym, w tym unijnym. Na

jektów uzasadnioną opinię zgłosiła tylko jedna izba. Por. Załącznik do sprawozdania Komisji: Sprawozdanie roczne za rok $2017 \mathrm{w}$ sprawie stosowania zasad pomocniczości i proporcjonalności, $\operatorname{COM}(2018) 490$ final.

${ }^{35}$ Por. Czarny et al. (2014): 147-192; Balicki (2019): 166-167. 
tle przedstawionych wyżej uwag dotyczących kontroli przestrzegania zasady pomocniczości wyraźnie zaznaczone zostało znaczenie dialogu politycznego, w który angażuja się parlamenty narodowe. Wobec deficytów procedur prawnych to właśnie w ramach tego dialogu parlamenty narodowe wywierają rzeczywisty wpływ na proces stanowienia prawa UE.

W związku z dialogiem politycznym pojawiają się jednak doniosłe zagadnienia dotyczące podstaw prawnych reprezentowania stanowiska Sejmu poza granicami państwa. Nie jest jasne w szczególności, czy Sejm w ogóle dysponuje (poza szczególnymi i wąsko określonymi uprawnieniami, które wynikaja wprost z traktatów) kompetencją do formułowania i prezentowania na forum UE własnego stanowiska, odmiennego od stanowiska innych organów władzy państwowej, przede wszystkim Rady Ministrów. Z pytaniem tym wiąże się konstytucyjna kwestia, czy prezentowanie takiego stanowiska przez Sejm nie stanowi przejawu prowadzenia polityki zagranicznej państwa, które jest zastrzeżone dla Rady Ministrów (art. 146 ust. 1 Konstytucji) ${ }^{36}$. W związku z tymi podstawowymi pytaniami pojawiają się liczne kwestie pochodne. Watpliwości budzi między innymi to, czy reprezentowanie stanowiska Sejmu na zewnątrz przez podmioty inne niż Marszałek Sejmu (lub na podstawie jego upoważnienia) jest możliwe do pogodzenia z art. 110 ust. 2 in fine Konstytucji (Marszałek Sejmu reprezentuje Sejm na zewnątrz). Nie ma więc jasności, czy stanowisko Sejmu może być prezentowane na forum UE przez Komisję ds. UE lub członków tej komisji ani w czyim imieniu podmioty te występuja, przedstawiajac stanowisko na forum UE (art. w ramach COSAC). Kwestie te zostaja w tym miejscu wyłącznie zasygnalizowane. Ewidentny jest brak regulacyjny dotyczący tych zagadnień.

Tytułem ogólnego komentarza zaznaczyć można pogląd, że stworzenie właściwych ram prawnych reprezentacji stanowiska Sejmu na forum unijnym, nawet w zakresie parlamentarnych uprawnień traktatowych, wymagałoby zasadniczo zmian konstytucyjnych ${ }^{37}$. Wszelkie zmiany regulaminowe dotyczace reprezentacji Sejmu i jego organów na forum UE muszą respektować ograniczenia konstytucyjne, w tym zasadę określoną w art. 110 ust. 2 Konstytucji. Uznać należy, że obecnie brak jest dostatecznych podstaw prawnych dla angażowania się przez Sejm i jego organy w dialog polityczny w UE - i wszelkie działania podejmowane przez niego w tym zakresie mogą być postrzegane jako problematyczne.

\section{PODSUMOWANIE}

Trudności w stosowaniu reguł prawnych dotyczących udziału Sejmu i jego organów w procedurach stanowienia prawa UE mają charakter systemowy. Efektywne korzystanie przez Sejm zarówno z uprawnień lizbońskich, jak

36 Por. Florczak-Wator, Czarny (2012): 22-23.

37 Projekty ustaw o zmianie Konstytucji Rzeczypospolitej Polskiej, druki nr 3598 i 3687, Sejm VI kadencji. Por. R. Balicki (2013): 185-196; Pudło (2014): 39-41. 
i z uprawnień krajowych dotyczących współpracy z Radą Ministrów w sprawach związanych z członkostwem Polski w Unii Europejskiej wymaga właściwego fundamentu ustrojowego. Przyjęte przez Trybunał Konstytucyjny przyporządkowanie rozwiązań zawartych w ustawie kooperacyjnej do funkcji ustawodawczej nie jest w tej mierze wystarczające i zawodzi jako podstawa wykładni, która polegałaby na powiązaniu reguł udziału Sejmu w stanowieniu prawa UE z szerszym kontekstem regulacyjnym dotyczącym stanowienia prawa w Polsce, pozwalając wyjaśniać liczne wątpliwości interpretacyjne. W rzeczywistości krajowa procedura ustawodawcza nie stanowi odpowiedniego punktu odniesienia działań, które podejmowane są przez Sejm w związku z tworzeniem prawa UE. W kluczowych obszarach udziału Sejmu w stanowieniu prawa UE takiego ogólnego tła regulacyjnego w ogóle brakuje. Reguły sejmowego zaangażowania w unijny proces decyzyjny stanowią wyizolowany komponent regulacyjny, który nie jest normatywnie powiązany z żadną inna regulacją dotycząca procedury parlamentarnej. Podobnie brak reguł prawnych dotyczących udziału Sejmu - i jego organów - we współpracy międzyparlamentarnej i reprezentowania stanowiska tych organów na zewnattrz - na forum UE.

Analiza praktyki sejmowej w zakresie tworzenia prawa UE prowadzi do wniosku, że udział Sejmu w tworzeniu prawa UE stanowi poważne i wciąż nierozwiązane wyzwanie ustrojowe.

Ziemowit Cieślik

Uniwersytet Kardynała Stefana Wyszyńskiego w Warszawie

z.cieslik@uksw.edu.pl

https://orcid.org/0000-0003-4345-0610

Adamiec, D. (2018). Prawne aspekty kontroli zasady pomocniczości przez parlamenty państw członkowskich Unii Europejskiej. Warszawa.

Balicki, R. (2013). Rozdział europejski w polskiej Konstytucji - rzecz o niezrealizowanym kompromisie konstytucyjnym z 2011 r., [w:] S. Dudzik, N. Półtorak, Prawo Unii Europejskiej a prawo konstytucyjne państw członkowskich. Warszawa: 185-196.

Balicki, R. (2019). Funkcja europejska Sejmu RP. Wrocław.

Barcz, J. (2009). Wytyczne polityki legislacyjnej i techniki prawodawczej. Zapewnienie skuteczności prawa Unii Europejskiej w polskim prawie krajowym. Warszawa.

Cieślik, Z. (2015a). Rola Sejmu w stanowieniu prawa Unii Europejskiej, [w:] B. Pawłowski (red.), Rola Sejmu w stanowieniu i wykonywaniu prawa Unii Europejskiej. Warszawa: 9-30.

Cieślik, Z. (2015b). Rola Sejmu w Unii Europejskiej, [w:] W. Odrowąż-Sypniewski (red.), Przewodnik poselski. Warszawa: 153-181.

Cieślik, Z. (2016). Założenia zmian w regulacji prawnej w dziedzinie funkcjonowania Komisji ds. Unii Europejskiej - materiał analityczny. Zeszyty Prawnicze BAS Nr 1/2016: 103-116.

Czarny, P., Szmyt, A., Dudek, D., Grądzka, I., Mojak, R., Wójtowicz, K. (2014). Opinie w sprawie niektórych aspektów udziału Sejmu RP w dialogu politycznym Unii Europejskiej. Przegląd Sejmowy 3(122): 147-192.

Florczak-Wątor, M., Czarny, P. (2012). Międzynarodowa współpraca Sejmu RP. Warszawa.

Lis-Staranowicz, D., Galster, J. (2010). O zjawisku europeizacji polskiego prawa konstytucyjnego. Przegląd Sejmowy 2(97): 29-51.

Mik, C. Pawłowski B. (2004). Ustawa o współpracy Rady Ministrów z Sejmem i Senatem w sprawach związanych z członkostwem Rzeczypospolitej Polskiej w Unii Europejskiej. Komentarz. Kwartalnik Prawa Publicznego 2: 249-277. 
Mik C., Pawłowski B. (2005). Glosa do wyroku Trybunału Konstytucyjnego z dnia 12 stycznia 2005 r. (sygn. akt K 24/04). Przegląd Sejmowy 3(68): 131-142.

Mik, C., Pawłowski, B. (2009). Współpraca Rady Ministrów z Sejmem i Senatem w sprawach związanych z członkostwem Rzeczypospolitej Polskiej w Unii Europejskiej. Warszawa.

Mik, C. (2010). Pozycja prawna parlamentów narodowych w Unii Europejskiej w świetle Traktatu z Lizbony. Ruch Prawniczy, Ekonomiczny i Socjologiczny 72(2): 45-87.

Mik, C. (2019). Parlamenty narodowe wobec zasady pomocniczości w świetle prawa i praktyki Unii Europejskiej. Warszawa.

Pawłowski, B. (2006). Sejmowa Komisja do Spraw Unii Europejskiej. Przegląd Sejmowy 3(74): $173-190$

Pudło, A. (2014). Rola parlamentu narodowego w sprawach UE po wejściu w życie Traktatu z Lizbony. Warszawa.

Serowaniec, M. (2016). Parlamentarne komisje do spraw europejskich. Warszawa.

Wojtyczek, K. (2018). Komisja do Spraw Unii Europejskiej, [w:] A. Szmyt, Komentarz do Regulaminu Sejmu Rzeczypospolitej Polskiej. Warszawa.

Wójtowicz, K. (2008). Funkcja kontrolna Sejmu w zakresie integracji europejskiej. Przegląd Sejmowy 3(86): 77-92.

\section{SELECTED LEGAL ISSUES CONCERNING THE PARTICIPATION OF THE POLISH SEJM IN THE MAKING OF EUROPEAN UNION LAW}

\section{$\mathrm{Su} \mathrm{m}$ m a r y}

Polish membership in the European Union finds its expression, among other things, in the powers of the Polish Sejm to participate in the European law-making process. The rules of this participation are provided for in the heterogeneous, fluctuating and evolving body of European and domestic law. Its complex nature, stretching between the constitutional foundations of political power, on the one hand, and the procedural matters of the parliamentary practice, on the other, offers a wide range of legal challenges to anyone who applies it. The paper aims to reveal that diversity and addresses some aspects of parliamentary practice when dealing with matters involving the EU. The issues of concern are selected with respect to the experience gained and best practice developed by the Sejm's legal services: the Legislative Bureau and the Bureau of Research. All of them are systemic and - as it is argued - derived directly from the still unsettled question of the constitutional basis for the newly acquired competences of the national parliament to act on the European stage. The paper deals with the accountability of the Sejm's committee for EU matters, cross-border interparliamentary cooperation and the subsidiarity check, as well as the legal representation of the Sejm in the European forum.

Keywords: European Union; Lisbon Treaty; national parliaments 